\title{
Germline deletions in the EPCAM gene as a cause of Lynch syndrome - literature review
}

\author{
Katarzyna Tutlewska*, Jan Lubinski and Grzegorz Kurzawski
}

\begin{abstract}
Lynch syndrome (clinically referred to as HNPCC - Hereditary Non-Polyposis Colorectal Cancer) is a frequent, autosomal, dominantly-inherited cancer predisposition syndrome caused by various germline alterations that affect DNA mismatch repair genes, mainly MLH1 and MSH2. Patients inheriting this predisposition are susceptible to colorectal, endometrial and other extracolonic tumors. It has recently been shown that germline deletions of the last few exons of the EPCAM gene are involved in the etiology of Lynch syndrome. Such constitutional mutations lead to subsequent epigenetic silencing of a neighbouring gene, here, MSH2, causing Lynch syndrome. Thus, deletions of the last few exons of EPCAM constitute a distinct class of mutations associated with HNPCC. Worldwide, several investigators have reported families with EPCAM 3'end deletions. The risk of colorectal cancer in carriers of EPCAM deletions is comparable to situations when patients are MSH2 mutation carriers, and is associated with high expression levels of EPCAM in colorectal cancer stem cells. A lower risk of endometrial cancer was also reported. Until now the standard diagnostic tests for Lynch syndrome have contained analyses such as immunohistochemistry and tests for microsatellite instability of mismatch repair genes. The identification of EPCAM deletions or larger EPCAM-MSH2 deletions should be included in routine mutation screening, as this has implications for cancer predisposition.
\end{abstract}

Keywords: Lynch syndrome, EPCAM gene, Colon cancer, MSH2 hypermethylation

\section{Introduction}

Lynch Syndrome (LS; or previously HNPCC - Hereditary Non-Polyposis Colorectal Cancer) is one of the most common cancer susceptibility syndromes, which accounts for approximately $1-4 \%$ of all colon cancer cases [1]. It is characterized by an early onset of ColoRectal Cancer $(\mathrm{CRC})$ and increased risk for the occurrence of several extra-colonic malignancies, in particular endometrial cancer [2]. In the largest published series $3,1 \%$ of colorectal cases have been familiar to LS [3]. HNPCC is caused by inactivating germline mutations in the MisMatch Repair (MMR) system genes (mainly MSH2, MLH1, MSH6, but also PMS2) [4]. According to data from NCBI base $M L H 1$ and $\mathrm{MSH} 2$ mutations account for about $90 \%$ of all mutations connected with Lynch syndrome; MHS6 accounts for $7-10 \%$ and PMS2 is found in less than $5 \%$ of these alterations. According to recent studies there is another

\footnotetext{
* Correspondence: k.tutlewska@wp.pl

Department of Genetics and Pathology, International Hereditary Cancer Center, Pomeranian Medical University, Połabska 4, 70-115, Szczecin, Poland
}

1-3\% of LS patients within the Dutch and German populations) and this is the EPCAM gene (Figure 1) [5].

Lynch syndrome-associated tumors are usually characterized by DNA mismatch repair deficiency, and result from a second somatic event which inactivates the remaining functional mismatch repair gene allele [6,7]. As a consequence of lack of mismatch repair, tumorigenesis is promoted by secondary mutations that accumulate at short repetitive sequences, a phenotype termed "high level microsatellite instability" (high-MSI).

In other words, a MMR gene defect in one allele gives susceptibility to further mutations which may affect second allele cause lack of mismatch repair function in cell. This results in an accumulation of mutations in coding and non-coding microsatellites in such tumors: so-called "microsatellite instability" (MSI), which is a characteristic feature of more than $95 \%$ of LS-associated CRCs [8], in addition to the loss of expression of the mutated mismatch repair gene [9]. Carriers of mutations in $M L H 1$, MSH2 or MSH6 have a 30-80\% cumulative risk of developing colorectal cancer and women have additional $27-71 \%$ 


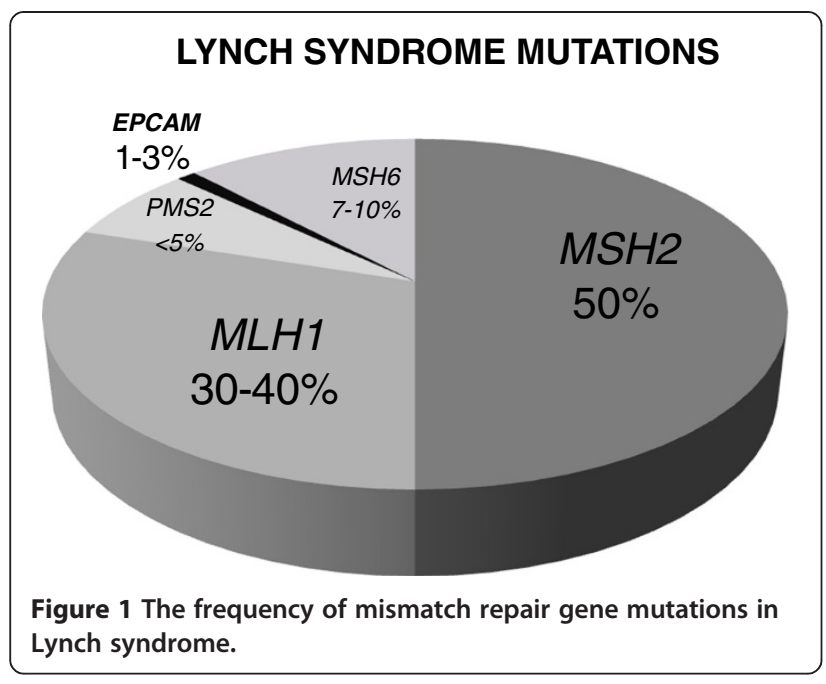

cumulative risk of endometrial cancer below age 70 years [2]. The main clinical features are an early age of onset and the occurrence of multiple tumors.

Appropriate diagnosis of LS may curried out in two major ways. One of them is to focus on an adequate family history in all patients visiting a physician. The revised Bethesda guidelines are probably the most common used criteria for selecting patients with CRC for further molecular tests $[10,11]$ (Table 1 ). The other way is systematic testing for all patients with CRC for loss of MMR function by means of high level microsatellite instability in tumor tissue or immunohistochemistry (ImmunoHistoChemistry, IHC). The advantage of the immunohistochemistry, is also allowing prediction of which mismatch repair gene is likely to be affected by a germline mutation [10]. In our International Hereditary Cancer Center patients are classified to Lynch syndrome according to characteristic clinical features or criteria and pedigrees typical for Lynch syndrome, what is

Table 1 Revised Bethesda guidelines for testing colorectal tumors for microsatellite instability (MSI)

\footnotetext{
1 Colorectal cancer diagnosed below 50 years of age.

2 Presence of synchronous, metachronous colorectal, or other Lynch syndrome-associated* tumors, regardless of age.

3 Colorectal cancer with high-MSI*, histology diagnosed in a patient who is less than 60 years of age.

4 Colorectal cancer diagnosed with one or more first-degree relatives with Lynch syndrome - associated tumors*, with one of the cancers being diagnosed under age 50 years.

5 Colorectal cancer diagnosed in two or more first or second degree relatives with Lynch syndrome-associated tumors* regardless of age

*Lynch syndrome-associated tumors: tumors of the endometrium, small bowel, or urinary tract; high-MSI = high level microsatellite instability in tumors refers to changes in two or more of the five $\mathrm{NCl}$-recommended panels of microsatellite markers.

Revised Bethesda guidelines for hereditary nonpolyposis colorectal cancer [Lynch syndrome] and microsatellite instability (Umar A, Boland CR, Terdiman JP, et al. (2004).
}

presented by Kladny and Lubinski [12]. An example of a pedigree of a family with definitive HNPCC and EPCAM carriers is shown in Figure 2.

In some individuals with Lynch syndrome the MMR genes mutation search fails. This group is of particular interest to researchers, who trying to find the genetic factors causing the disease. In some LS patients it have been shown that MMR genes methylation cause disease occurence [13-16]. Some evidence for this came from studies in which the $M L H 1$ gene was the target of methylation in germline tissues in HNPCC patients who were not carriers of a germline MLH1 mutation [17]. Moreover, heritable germline epimutations in $\mathrm{MSH} 2$ have been reported as well, in some MMR germlinemutation-negative LS families [18].

A new mechanism of inactivating $\mathrm{MSH} 2$ gene was therefore predicted. In multiple patients in which LS was suspected, with no germline mutation found in the MMR genes, a heterozygous germline deletion was identified encompassing the polyadenylation site located in the last two exons [8,9] of the EPCAM gene (OMIM\#185535, formerly known as TACSTD1) [19]. Such deletions disrupt the 3' end of the EPCAM gene, leading to transcriptional read-through of the mutated $E P C A M$ allele and epigenetic inactivation, and silencing of, its neighbouring gene MSH2. MSH2 is located $17 \mathrm{~kb}$ downstream of EPCAM on chromosome 2, and causes Lynch syndrome [20]. This epigenetic inactivation is restricted only to cells expressing EPCAM, and therefore patients who carry EPCAM deletions show mosaic patterns of $M S H 2$ inactivation that, compared with carriers of a mutation in $\mathrm{MSH} 2$, may lead to differences in tumor occurrence or spectrum [20]. What is interesting, high expression of EPCAM in colorectal cancer stem cells answers the question of why carriers with an EPCAM 3' end deletion have a substantially increased risk of colon cancer.

Kempers and colleagues (2011) in their studies established different cancer risks associated with EPCAM deletions, depending on whether a deletion affects only the $E P C A M$ gene or both the EPCAM and its neighboring gene $M S H 2$ (EPCAM-MSH2). These risks were then compared with those for Lynch syndrome carriers of a mutation in MMR genes. This was the first study that described the cumulative cancer risks and cancer profile of EPCAM deletion carriers [21]. They reported a low risk for endometrial cancer in patients with deletions of EPCAM compared to that with a mutation in an MMR gene. Of the 194 individuals with an EPCAM mutation included in their studies, 16 developed cancers other than colonic or endometrial [duodenal: $\mathrm{n}=3$; and pancreatic: $\mathrm{n}=4$; were the most common].

An interesting recent study by Kloor et al. (2011) revealed that concomitant lack of EPCAM and $M S H 2$ protein expression is a feature highly specific for cancers 


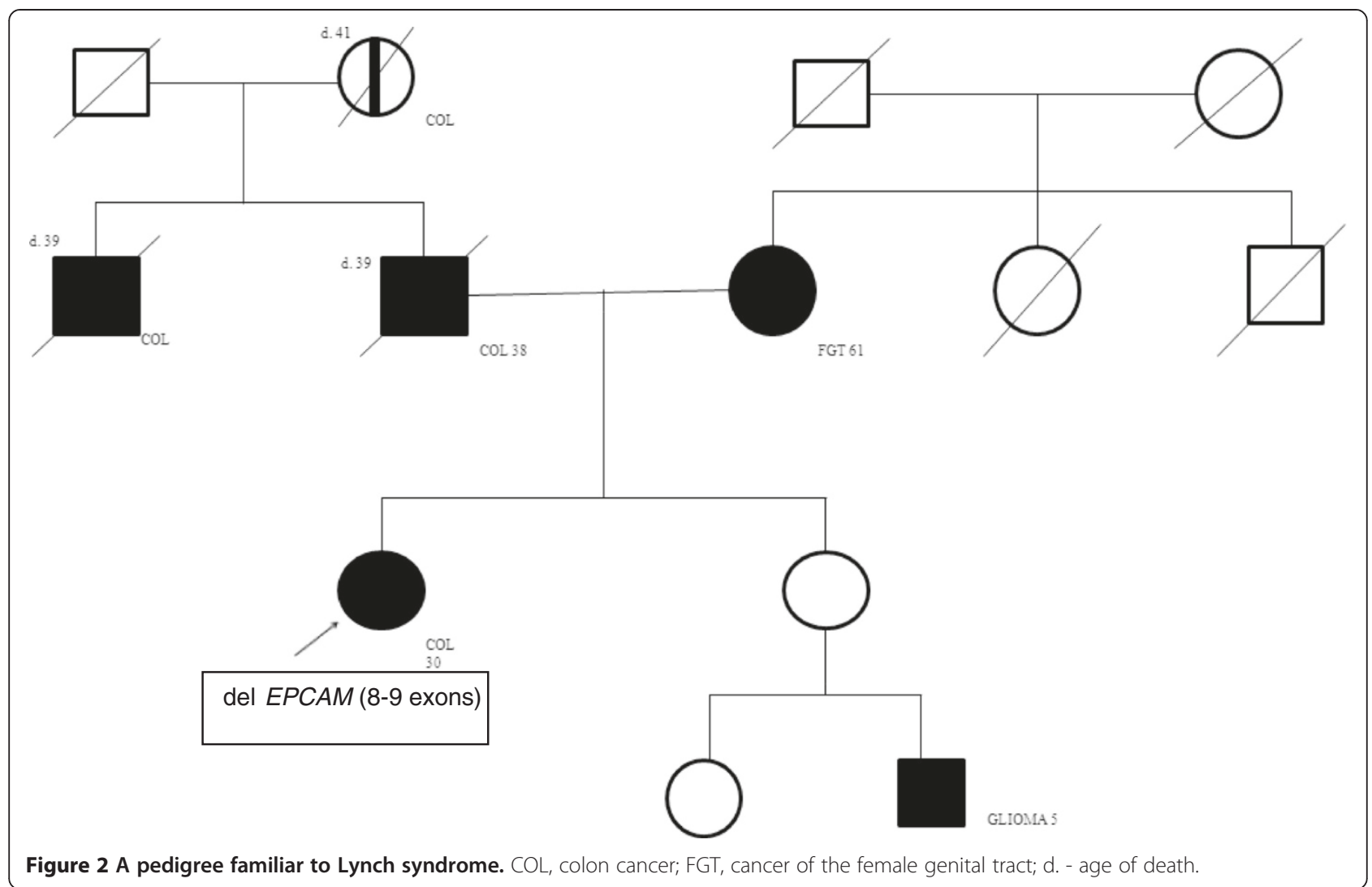

from EPCAM deletion carriers, suggesting EPCAM immunohistochemistry as a potential analysis tool for the identification of Lynch syndrome patients with EPCAM germline deletions [22]. However, there was a problem with this approach, because EPCAM protein expression was retained in some cancers from EPCAM mutation carriers. Investigators have not determined the relationship between EPCAM protein expression status in cancers and localization of an EPCAM germline deletion [22]. This is why Huth et al. (2012) hypothesized that a second somatic hit (leading to $M S H 2$ inactivation) determined EPCAM expression in tumor cells. (They analyzed four carcinomas and two adenomas from $E P C A M$ deletion carriers for EPCAM protein expression and allelic deletion status of the EPCAM gene [7].

\section{The EPCAM gene}

The EPCAM gene (Epithelial Cellular Adhesion Molecule; alternative name TACSTD1 - Tumor Associated Calcium Signal TransDucer 1, OMIM\#185535) encodes a carcinoma-associated antigen which is a glycosylated member of a family that includes at least two type I membrane proteins [23]. It is located on the short (p) arm of chromosome 2 at position 21. More precisely, from base pair 47,596,286 to base pair 47,614,166 on chromosomes 2 .
In healthy tissues EPCAM is located in the basolateral membrane but in cancer tissues this protein is homogeneously distributed on the cell surface. EPCAM is not only implicated in mediating epithelial-specific intercellular adhesion, but also in intracellular signaling, migration, proliferation and differentiation. The extracellular part of $E P C A M$ contains an epidermal growth factor-like domain and a presumed thyroglobulin domain. Activation of $E P C A M$ signaling is mediated by intra-membrane proteolysis through which the extracellular domain is shed and the intracellular domain (EpICD) is released into the cytoplasm (Figure 3). Here it becomes part of a large nuclear complex containing the transcriptional regulators $\beta$ catenin and Lef, both components of the wht signaling pathway [2].

It has, therefore, been speculated that EPCAM on normal epithelia is sequestered and, therefore, much less accessible to antibodies than EPCAM in cancer tissue, where it is homogeneously distributed on the cancer cell surface [23].

The antigen EPCAM is presently being used as a target for immunotherapy treatment of human carcinomas.

Deletions involving the transcription termination signal of EPCAM are causative in $1 \%$ to $2.8 \%$ of families with Lynch syndrome. Other EPCAM alterations that don't affect the transcription termination signal cause autosomal-recessive congenital tufting enteropathy [24]. 


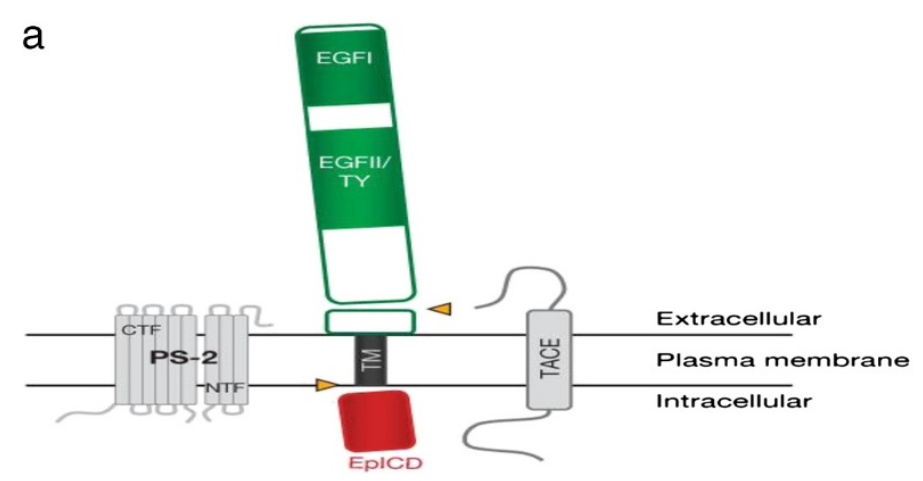

b

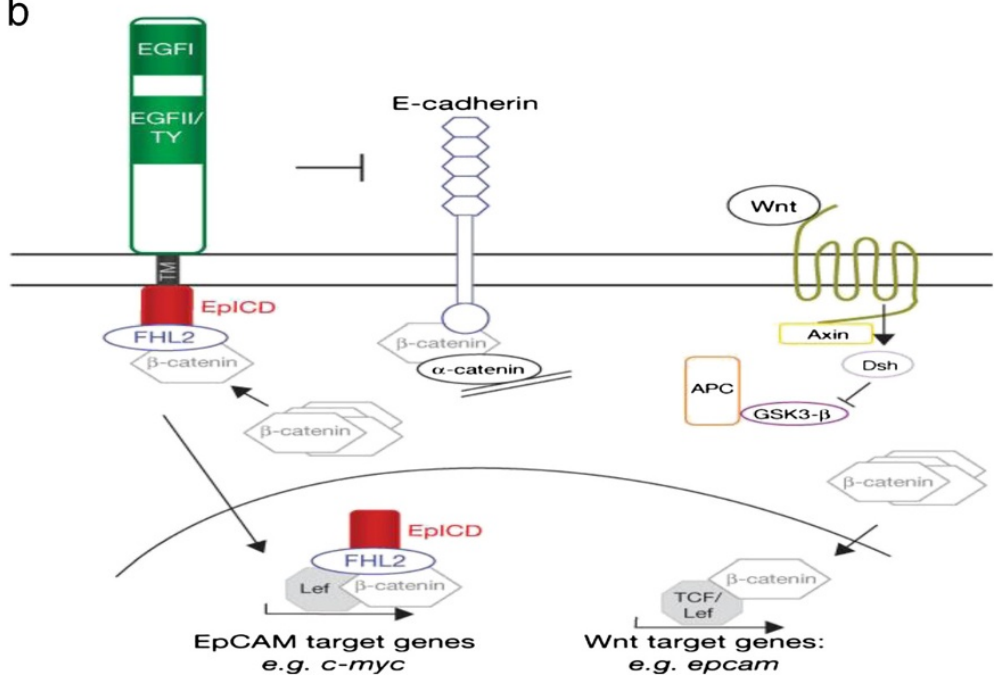

Figure 3 Schematic representation of signaling pathways involving EPCAM, proposed by Maetzel D et al. (2009) [23]. (a) Cleavage of EPCAM by TACE and PS-2. (b) EPCAM signalling and possible cross-talk with E-cadherin and Wnt pathways. EPCAM signalling is induced by RIP, leading to EpICD nuclear translocation in a complex with FHL2 and -catenin. Within the nucleus, the EpICD complex interacts with Lef- 1 and contacts DNA. Upon interference with E-cadherin, EPCAM may increase the availability of its interaction partner -catenin in the soluble fraction. Cross-talk with the Wnt pathway is conceivable at the level of -catenin and Lef-1 interactions with EpICD, and is known for induction of the EPCAM promoter by Tcf4 (Maetzel D, Denzel S, Mack B, et al., Nature Cell Biology 11, 162 - 171, 2009).

\section{Epigenetic silencing of $M S H 2$}

EPCAM deletions cause $M S H 2$ gene silencing by a mechanism known as promoter hypermethylation. Additional methyl groups attached to the $\mathrm{MSH} 2$ promoter reduce the expression of the $M S H 2$ gene, which means that less protein is produced in epithelial cells. The MSH2 protein plays an essential role in repairing mistakes in DNA, so loss of this protein prevents proper DNA repair and mistakes accumulate as the cells continue to divide. These mistakes can lead to uncontrolled cell growth and an increased risk of cancer. Lack of EPCAM immunostaining in MSH2-negative CRCs is indicative of EPCAM gene alterations, and therefore Musulen Eva and Blanco Ignacio have recommended (2013) the performance of EPCAM immunohistochemistry before MLPA (Multiplex Ligation-dependent Probe Amplification) analysis [4].
Van der Klift and his group (2005) first reported deletions encompassing the 3'end of EPCAM which did not affect the open reading frame of $M S H 2$, in a cohort of LS-suspected patients [25]. Five years later a relationship between deletion of the $3^{\prime}$ end of EPCAM and inactivation of $\mathrm{MSH} 2$ was independently reported by two groups. Kovacs et al. (2009) detected four different deletions encompassing the last few exons of EPCAM, in five families with one or more tumors exhibiting microsatellite instability and loss of the MSH2 protein [18]. At the same time, Ligtenberg et al. (2009) detected similar EPCAM 3' end deletions in four Dutch families with colorectal cancer, showing high microsatellite instability and loss of the MSH2 protein, but in which no mutations in $\mathrm{MSH} 2$ were found. Additionally, in these families the deletion co-segregated with the occurrence of $M S H 2$-deficient tumors and, in addition, was found to 
lead to transcriptional read-through into the $M S H 2$ locus [19]. What's more, Ligtenberg's group (2012) noticed that this transcriptional read-through induced monoallelic hypermethylation of the $M S H 2$ promoter present on the same allele as the 3' end EPCAM deletion. Sequence analysis defined the deletion breakpoints, with a deletion of 4909 bp denoted 859-1462 "1999del from EPCAM cDNA. Haplotype analysis suggested that this mutation originated from a common founder. All six high-MSI tumors from these families showed methylation of the $\mathrm{MSH} 2$ promoter by methylation-specific PCR and subsequent bisulfite sequencing (Table 2). These observations convincingly indicated that deletion of the 3' end of EPCAM can lead to inactivation of the $M S H 2$ promoter and, therefore, should be considered a novel cause of Lynch syndrome [2].
Ligtenberg et al. (2009) also analyzed the family reported by Chan et al. (2006) with heritable $M S H 2$ promoter methylation and identified a heterozygous deletion of 22.8 $\mathrm{kb}$ (EPCAM cDNA, 555+894_+14194del) that segregated with the disease [19]. The deletion extended from intron 5 of the EPCAM gene to approximately $2.4 \mathrm{~kb}$ upstream of $M S H 2$, encompassing the 3' end of EPCAM and leaving the $M S H 2$ promoter intact. The same authors identified the same mutation in another Chinese family, where there was no evidence for a founder mutation. Analyses such as RT-PCR and methylation-specific PCR of tissue samples from affected individuals showed that methylation of MSH2 was limited to EPCAM-expressing cells (Table 2).

Huth et al. (2012) reported that lack of EPCAM expression occurs in many, but not all, tumors from Lynch

Table 2 Characteristics of the EPCAM deletions compiled by Kuiper et al., 2011 and Mur et al., 2013

\begin{tabular}{|c|c|c|c|c|c|c|c|c|}
\hline No & Nomenclature & Population & $\begin{array}{l}\text { Number } \\
\text { of families }\end{array}$ & $\begin{array}{l}\text { Deleted } \\
\text { EPCAM } \\
\text { exons }\end{array}$ & $\begin{array}{l}\text { Size } \\
\text { deletion } \\
\text { (bp) }\end{array}$ & $\begin{array}{l}\text { Breakpoint } \\
\text { homology } \\
\text { (bp) }\end{array}$ & $\begin{array}{l}\text { Type of } \\
\text { repeat } \\
\text { element }\end{array}$ & Reference \\
\hline 1 & $\begin{array}{l}\text { c.859-1462_*1999del } \\
\text { (founder mutation) }\end{array}$ & Dutch & 16 & $8+9$ & 4909 & 6 & AluSx AluSq & $\begin{array}{l}\text { Ligtenberg et al., } 2009 \\
\text { Niessen et al., } 2009\end{array}$ \\
\hline 2 & c.491+529_*874del & German & 2 & $5-9$ & 11.660 & 25 & Alusg/ Alusg/x & Kuiper et al., 2011 \\
\hline 3 & c.492-509_*13721del & Swiss & 2 & $5-9$ & 23.829 & 24 & AluSp/AluSg & Van der Klift et al., 2005 \\
\hline 4 & c.555+402_*1220del & Hungarian & 1 & $6-9$ & 10.355 & 12 & AluSx/AluSx & Kovacs et al., 2009 \\
\hline 5 & c.555+927_*14226del & $\begin{array}{l}\text { Chinese/ } \\
\text { American }\end{array}$ & 3 & $6-9$ & 22.836 & 32 & AluY/AluSC & Ligtenberg et al., 2009 \\
\hline 6 & c.555+901_*4492del & American & 2 & $6-9$ & 13.128 & 15 & AluY/AluSX & Kuiper et al., 2011 \\
\hline 7 & c.858+1244_*4562del & Dutch & 1 & $8+9$ & 9963 & 18 & AluSp/AluSx & Kuiper et al., 2011 \\
\hline 8 & c.858+1211_4529del & German & 1 & $8+9$ & 9963 & 8 & AluSp/AluSx & Kuiper et al., 2011 \\
\hline 9 & $\begin{array}{l}\text { c.858+1364_*4793 } \\
\text { del_insAG }\end{array}$ & German & 1 & $8+9$ & 10.074 & - & AluSp/FLAM-C Alu & Kuiper et al., 2011 \\
\hline 10 & c. $858+2478{ }^{*} 4507 \mathrm{del}$ & $\begin{array}{l}\text { German/ } \\
\text { Hungarian }\end{array}$ & 3 & $8+9$ & 8674 & 14 & Alusp/AluSx & Kovacs et al., 2009 \\
\hline 11 & c.859-2524_*10762del & Hungarian & 1 & $8+9$ & 14.734 & 15 & AluSp/AluSp & Kuiper et al., 2011 \\
\hline 12 & c.859-353_*618del & English & 1 & $8+9$ & 2419 & 3 & AluSx/AluSg & Kuiper et al., 2011 \\
\hline 13 & c.859-670_*530del & German & 1 & $8+9$ & 2648 & 18 & AluSx/AluSg & Kuiper et al., 2011 \\
\hline 14 & c.859-689_*14697del & German\# & 4 & $8+9$ & 16.834 & 24 & AluSx/AluSx & Kuiper et al., 2011 \\
\hline 15 & c.859-696_*391del & Hungarian & 1 & $8+9$ & 6058 & 19 & AluSx/AluJo & Kovacs et al., 2009 \\
\hline 16 & c.859-1682_*2116del & German & 1 & $8+9$ & 5246 & 13 & AluJb/Alusq & Kuiper et al., 2011 \\
\hline 17 & c.859-1605_*5862del & American & 1 & $8+9$ & 8879 & 10 & AluJb/AluSa & Kuiper et al., 2011 \\
\hline 18 & c.859-645_*10911del & American & 1 & $8+9$ & 13.004 & 14 & AluSx/AluSx & Van der Klift et al., 2005 \\
\hline 19 & c.423-545_*3903del & German & 1 & $4-9$ & 16.500 & 7 & Alusq/AluJo & Kuiper et al., 2011 \\
\hline 20 & $\begin{array}{l}\text { c.859-1860_MSH2: } \\
\text { 646-254del }\end{array}$ & Spanish & 1 & $\begin{array}{l}8+9 \text { and exons } \\
1-3 \text { of } \mathrm{MSH} 2\end{array}$ & 28.900 & 3 & AluY/AluSX & Cabornero et al., 2011 \\
\hline 21 & $\begin{array}{l}\text { c. } 858+2568{ }^{*} 4596 \mathrm{del} \\
\text { (founder mutation) }\end{array}$ & Spanish & 3 & $8+9$ & 8672 & 32 & Alusp/AluSx & Mur et al., 2013 \\
\hline 22 & c.858+2488_*7469del & Spanish & 2 & $8+9$ & 11.600 & 19 & AluSp/AluSp & Mur et al., 2013 \\
\hline 23 & c.555+894_*14194del & Chinese & 2 & $\begin{array}{l}\text { intron5-2.4 kb } \\
\text { upstream of } \\
\mathrm{MSH} 2 \text {; }\end{array}$ & $22.8 \mathrm{~kb}$ & 6 & Alusx/AluSq & Ligtenberg et al., 2009 \\
\hline
\end{tabular}


syndrome patients with EPCAM germline deletions [7]. The differences in EPCAM expression were not related to the localization of EPCAM germline deletions. Therefore they hypothesized that a type of second somatic hit, leading to $\mathrm{MSH} 2$ inactivation during tumor development, determines EPCAM expression in the tumor cells. In four out of six tumors, investigators detected lack of EPCAM expression accompanied by biallelic deletions affecting the $E P C A M$ gene. In contrast, monoallelic retention of the EPCAM gene was observed in the remaining two tumors with retained EPCAM protein expression. These results indicate that EPCAM expression in tumors from $E P C A M$ deletion carriers depends on the localization of a second somatic hit that inactivates $M S H 2$. These data demonstrate the lack of EPCAM protein expression observed in tumors from a combination of a germline mutation and second somatic hit. They also show that heterozygous $E P C A M$ germline deletions are not necessarily associated with loss of EPCAM expression in tumor tissue. The detection of a somatic mutational event causing $M S H 2$ inactivation in one of the EPCAM positive tumors, explains why some tumors from $E P C A M$ deletion carriers show loss of $M S H 2$, but retained EPCAM expression [7].

The incidence of EPCAM deletions appeared to vary between populations and was found to represent at least 1-3\% of the explained Lynch syndrome families. Detailed analysis of the EPCAM deletions revealed their range of variability as well as their $A l u$-repeat-mediated origin as a likely mechanism for these rearrangements [5]. Indeed, all EPCAM deletion breakpoints characterized by various authors were located within repetitive $A l u$ elements (Table 2).

Alu elements are a family of Short Interspersed Nuclear Elements (SINE) found only in primates and comprise about $10.5 \%$ of the human genome [26]. These are mobile retrotransposable elements that also contain a recombinogenic motive, leading them to recombinational activity. However, their mobility and susceptibility to recombination is presumably tempered by host-defensive methylation of these CpG-rich elements [26]. Deletions formed through unequal $A l u$-mediated homologous recombination involve a cross-over at regions of shared sequence identity between two parental Alu elements located in cis in the same orientation, with loss of the loop of intervening genomic sequence during the exchange. These deletions are identifiable by signatory tracts of perfect $A l u$-derived sequence identity, overlapping or adjacent to the deletion breakpoints, such that the deletion junction cannot be mapped to a precise nucleotide. Perez-Cabornero and colleagues (2011) mapped each of the deletion breakpoints to within short stretches of fused $A l u$ sequences that shared close homology to their respective parental Alu elements [27]. This is the first such finding to date and prompted a revisitation of the role of $A l u$ elements in the causation of Lynch syndrome.

\section{Prevalence of EPCAM deletions}

Worldwide, EPCAM deletions were found to be present in various populations from different geographic origins $[18,28]$ (Table 2). Their prevalence was found to vary between these populations, partly because of the presence of various founder mutations [5], and to account for up to $10 \%$ of the $M S H 2$ inactivating mutations. All Lynch syndrome-associated tumors from EPCAM deletion carriers that were available for testing showed hypermethylation of the MSH2 promoter [13]. Detailed analyses of the breakpoints of these deletions indicated that they predominantly originate from $\mathrm{Alu}$ repeat-mediated recombination events [2]. A wide variety of different deletions could be reflected in different recombination events caused by a high number of Alu repeats spread across this locus [9].

This situation was documented by Grandval et al. [29], namely EPCAM deletions in three out of seven of their patients as de novo mutations, which probably reflects the relatively high $\mathrm{Alu}$ repeat-mediated recombination frequency at this locus [2].

Our unpublished data from the studies of 55 patients with LS indicates that deletions of 8 and 9 exons of the EPCAM gene determine $7 \%$ of LS cases without MMR mutation.

\section{Tumor spectrum of EPCAM deletions}

Constitutional rearrangements affecting the open reading frame of genes typically lead to constitutive inactivation of these genes, irrespective of the cell type. In contrast, in EPCAM 3' end deletion carriers $M S H 2$ inactivation is cell type-specific, since the epigenetic silencing of $M S H 2$ is restricted to cells in which the EPCAM locus is active and transcriptional read-through occurs. The outcome of this is that carriers of EPCAM deletions show mosaic patterns of $M S H 2$ inactivation. This phenomenon involving the inactivation of one of the EPCAM alleles might lead to a tumor spectrum that is different from that of germline mutations directly affecting $\mathrm{MSH} 2$ [2].

Some investigators have compared the cancer risk for carriers of an intragenic $M S H 2$ mutation, a combined EPCAM-MSH2 deletion, and a deletion of the $3^{\prime}$ end of EPCAM. The colorectal cancer risk of EPCAM mutation carriers, as reflected by the mean age at diagnosis and the cumulative risk by age 70 years, was similar to that of EPCAM-MSH2 or MSH2 mutation carriers. In contrast, the cumulative risk of endometrial cancer by the age of 70 years was significantly lower for $3^{\prime}$ end $E P C A M$ deletion carriers than for combined EPCAM-MSH2 deletion carriers and $M S H 2$ mutation carriers (Table 3). Importantly, the comparison of the tumor risk between the EPCAM and EPCAM-MSH2 deletion carriers indicates that the difference in endometrial cancer risk relates to the mosaic inactivation of $\mathrm{MSH} 2$ and not to a constitutive loss 
Table 3 Heterozygous inactivation of EPCAM and/or $M S H 2$ in colorectal and endometrial cancer risk of carriers of different germline mutations inactivating $\mathrm{MSH2}$, elaborated by Ligtenberg et al. (2012)

\begin{tabular}{llllll}
\hline & \multicolumn{2}{l}{$\begin{array}{l}\text { Gene } \\
\text { inactivation }\end{array}$} & & \multicolumn{2}{l}{ Cancer risk } \\
\cline { 2 - 3 } \cline { 5 - 6 } & EPCAM & MSH2 & & Colorectal & Endometrial \\
\hline 3' end EPCAM deletion & Yes & Mosaic & High & Low \\
EPCAM-MSH2 deletion & Yes & Yes & & High & High \\
Intragenic MSH2 deletion & No & Yes & & High & High \\
\hline
\end{tabular}

of EPCAM [20]. A relatively low incidence of endometrial tumors was also observed in several other studies [30].

As mentioned above, the average age at onset, the risk of colorectal cancer and the tumor phenotype in EPCAM deletion carriers are comparable to those carrying a typical mismatch repair gene mutation in $M L H 1$ or $M S H 2$, whereas the cumulative risk of endometrial cancer is much lower [5,20]. In EPCAM deletion carriers there is a relatively low risk of endometrial cancer, which is the second most prevalent Lynch syndrome-associated malignancy in carriers of a mismatch repair mutation. EPCAM deletion carriers will probably be more easily recognized than carriers of an MSH6 mutation, whose colorectal cancer risk is lower with a higher age of onset [2].

In the cohort from Grandval et al. (2012), EPCAM deletion carriers only developed tumors of the digestive tract. Their risk to develop colorectal cancer was particularly high, only two of the 29 deletion carriers aged over 30 being unaffected [29].

\section{EPCAM founder deletions}

A number of founder mutations have been identified in MMR genes, but only one affecting the EPCAM gene [19,31]. This $4.9 \mathrm{~kb} E P C A M$ founder deletion, thus far observed by Ligtenberg et al. in seven Dutch families, was found to be present in nine out of ten additional families from The Netherlands, but in none of the families from other geographic origins, thus confirming its founder nature (Table 2) [5]. In 2013, Mur and Pineda detected two EPCAM deletions: c. $858+2568$ *4596del (found in three families) and c.858+2488 "7469del (in two families; all five were unrelated Spanish LS families). Furthermore, they describe the EPCAM c.858+2568_ "4596del mutation as the first reported EPCAM founder mutation in Spain (Table 2) [32].

In addition, six EPCAM deletions were identified in more than one family originating from Germany (deletions 2 and 14 in Table $2, n=2$ and $n=4$, respectively), Switzerland (deletion 3 in Table 2, $n=2$ ), and the United States (deletion 6 in Table 2, $n=2$ ) or from multiple origins (deletions 5 and 10 in Table 2, $n=3$ ) [5].

\section{Diagnostics of EPCAM 3'end deletion carriers}

Mutational screening of carriers of 3'end deletions of EPCAM is based on matching the Amsterdam or Bethesda criteria and is associated with an MSI phenotype or loss of MMR protein expression in tumors.

Immunohistochemical analysis of MMR protein expression is a hallmark of Lynch syndrome diagnostics, but it cannot distinguish between EPCAM deletion carriers and $M S H 2$ mutation carriers [33]. The dependence of EPCAM expression on both germline and somatic alterations explains why EPCAM immunohistochemistry can yield inconspicuous results in a subset of tumors from EPCAM deletion carriers, namely if a second somatic $M S H 2$ inactivating hit does not affect the EPCAM gene [7]. Moreover, Huth and his team reported a lack of EPCAM protein expression in a colorectal adenoma, suggesting that EPCAM immunohistochemistry may detect $E P C A M$ deletions already at a precancerous stage [7].

Germline rearrangements in the EPCAM gene and $\mathrm{MSH} 2$ promoter methylation are detected by using multiplex ligation-dependent probe amplification (MLPA) analysis containing probes for a specific region $[9,19,32]$. Huth et al. (2012) revealed, following MLPA analysis, biallelic deletions affecting the EPCAM gene in four out of six analyzed tumors. In the remaining two tumors, no biallelic EPCAM deletions were observed, and the allelic profile obtained for the EPCAM gene region was identical in DNA isolated from tumor tissue and matched blood samples. All tumors showing biallelic deletions in the EPCAM gene region were negative for EPCAM protein expression, while EPCAM protein expression was retained in the tumors which retained a one normal EPCAM allele. These scientists also proved that the MLPA technique is applicable for the detection of heterozygous and homozygous deletions in DNA isolated from paraffin-embedded tumor tissue (when for example no blood is available) [7].

As a additional method for detecting specified deletions in the EPCAM gene, Ligtenberg and Kuiper (2009) used long range PCR and real-time quantitative RT-PCR. For long range PCR across the deletion, in Dutch families, a TAKARA PCR kit was used with primers on either side of the deletion. Further, they specified the deletion by direct-sequencing, using a forward primer in combination with an internal reverse primer. For the Chinese families they performed multiple long range PCRs, which yielded an aberrant amplicon suggestive of a large deletion mutation [19]. To detect fusion transcripts, a direct RT-PCR reaction or a nested-RT-PCR was performed [19,21].

Recently, Pritchard and his team from the USA (2012) notified a comprehensive and cost-effective test called "ColoSeq" that detects all classes of mutations in Lynch and polyposis syndrome genes, using solution-based 
targeted capture and next-generation sequencing [34]. Due to this technique they correctly identified 28/28 (100\%) pathogenic mutations in MLH1, MSH2, MSH6, $P M S 2, E P C A M, A P C$ and $M U T Y H$, including single nucleotide variants (SNVs), small insertions and deletions, and large copy number variants. These scientists focused on defining the sensitivity of heterozygous variant detection because pathogenic mutations in Lynch and polyposis syndromes are almost always heterozygous, except in the MUTYH gene. There was $100 \%$ reproducibility of mutation detection between independent runs [34]. The Coloseq assay demonstrated at least exon-level resolution for all large deletions and duplications, which was comparable or even better than the resolution of traditional approaches to these kind of mutations analysis such as MLPA, in which exact breakpoints could not be determined, because they are commonly in Alu or other repetitive DNA elements [34].

\section{Conclusions}

Based on previous worldwide results, there is a strong suggestion that implementation of EPCAM deletion mapping in routine diagnostics on suspected Lynch syndrome families should be considered. Some studies suggest that the frequency of EPCAM deletions as a cause of Lynch syndrome is up to $30 \%$ in patients with MSH2-negative tumors (from IHC results) or approximately $20 \%$ of LS patients without a mutation in MMR genes $[18,22]$.

This underlines the importance of EPCAM deletions in the Lynch syndrome, as it is a more frequent cause of LS than mutations in PMS2 or MSH6 [33].

The frequent occurrence of somatic deletions affecting the EPCAM gene as a second hit in tumors from $E P C A M$ deletion carriers suggests that the localization of somatic events inactivating mismatch repair genes in Lynch syndrome is not random, but related to the underlying germline mutation [7].

In conclusion, EPCAM 3'end deletions are a recurrent cause of Lynch syndrome, and detection should be implemented in routine Lynch syndrome diagnostics.

\section{Competing interests}

Authors declare that they have no competing interests.

\section{Authors' contributions}

Conception and design: $K T_{\text {; }}$ drafting the manuscript: $K T$; critical revision for important intelectual content: GK; final approval: KT, GK, JL. All authors read and approved the final manuscript.

\section{Acknowledgement}

The study was funded by Polish Ministry of Science and Higher Education (MNiSW), project number MB-158-77/13.

Received: 11 July 2013 Accepted: 9 August 2013

Published: 12 August 2013

\section{References}

1. Renkonen-Sinisalo L, Sampson JR, Stormorken A, Tejpar S, Thomas HJ, Wijnen J, Lubiński J, Müller H, Ponz De Leon M, Vasen HF, Möslein G, Alonso A, Aretz S, Bernstein I, Bertario L, Blanco I, Bulow S, Burn J, Capella G, Colas C, Engel C, Frayling I, Rahner N, Hes FJ, Hodgson S, Mecklin JP, Møller P, Myrhøj T, Nagengast FM, Parc Y: Recommendations to improve identification of hereditary and familial colorectal cancer in Europe. Fam Cancer 2010, 9:109-115.

2. Ligtenberg MJL, Kuiper RP, van Kessel AG, Hoogerbrugge N: EPCAM deletion carriers constitute a unique subgroup of Lynch syndrome patients. Fam Cancer 2012. 10.1007/s10689-012-9591-X.

3. Moreira L, Balaguer F, Lindor N, de la Chapelle A, Hampel H, Aaltonen LA, Hopper JL, Le Marchand L, Gallinger S, Newcomb PA, Haile R, Thibodeau SN, Gunawardena S, Jenkins MA, Buchanan DD, Potter JD, Baron JA, Ahnen DJ, Moreno V, Andreu M, Ponz De Leon M, Rustgi AK, Castells A: EPICOLON consortium: identification of Lynch syndrome among patients with colorectal cancer. JAMA 2012, 308:1555-65.

4. Musulen E, Blanco I, Carrato C, Fernandez-Figueras MT, Pineda M, Capella G, Ariza A: Usefulness of epithelial cell adhesion molecule expression in the algorithmic approach to Lynch syndrome identification. Hum Pathol 2013, 44:412-6.

5. Kuiper RP, Vissers LE, Venkatachalam R, Bodmer D, Hoenselaar E, Goossens M, Haufe A, Kamping E, Niessen RC, Hogervorst FB, Gille JJ, Redeker B, Tops $C M$, van Gijn ME, van den Ouweland AM, Rahner N, Steinke V, Kahl P, Holinski-Feder E, Morak M, Kloor M, Stemmler S, Betz B, Hutter P, Bunyan DJ, Syngal S, Culver JO, Graham T, Ligtenberg MJ: Recurrence and variability of germline EPCAM deletions in Lynch syndrome. Hum Mutat 2011, 32:407-14.

6. Hemminki A, Peltomäki $P$, Mecklin JP, Järvinen $H$, Salovaara R, Nyström-Lahti $\mathrm{M}$, de la Chapelle A, Aaltonen LA: Loss of the wild type MLH-1 gene is a feature of hereditary nonpolyposis colorectal cancer. Nature 1994 8:405-10.

7. Huth C, Kloor M, Voigt A, Bozukova G, Evers C, Gaspar H, Tariverdian M, Schirmacher $\mathrm{P}$, Doeberitz $\mathrm{M}$, Bläker $\mathrm{H}$ : The molecular basis of EPCAM expression loss in Lynch syndrome-associated tumors. Mod Pathol 2012, 25:911-6.

8. Peltomäki $P$, Lothe RA, Aaltonen LA, Pylkkänen L, Nyström-Lahti M, Seruca R, David L, Holm R, Ryberg D, Haugen A: Microsatellite instability is associated with tumors that characterized the hereditary non-polyposis carcinoma syndrome. Cancer Res 1993, 53:5853-5.

9. Guarinos C, Castillejo A, Barberá VM, Pérez-Carbonell L, Sánchez-Heras AB, Segura A, Guillén-Ponce C, Martínez-Cantó A, Castillejo MI, Egoavil CM, Jover R, Payá A, Alenda C, Soto JL: EPCAM Germ line deletions as causes of Lynch syndrome in Spanish patients. J Mol Diagn 2010, 12:765-70.

10. Vasen HF, Blanco I, Aktan-Collan K, Gopie JP, Alonso A, Aretz S, Bernstein I, Bertario L, Burn J, Capella G, Colas C, Engel C, Frayling IM, Genuardi M, Heinimann K, Hes FJ, Hodgson SV, Karagiannis JA, Lalloo F, Lindblom A, Mecklin JP, Møller P, Myrhoj T, Nagengast FM, Parc Y, Ponz De Leon M, Renkonen-Sinisalo L, Sampson JR, Stormorken A, Möslein G: Revised guidelines for the clinical management of Lynch syndrome (HNPCC): recommendations by a group of European experts. Gut 2013, 62:812-23.

11. Umar A, Boland CR, Terdiman JP, Syngal S, de la Chapelle A, Rüschoff J, Fishel R, Lindor NM, Burgart LJ, Hamelin R, Hamilton SR, Hiatt RA, Jass J, Lindblom A, Lynch HT, Peltomaki P, Ramsey SD, Rodriguez-Bigas MA, Vasen HF, Hawk ET, Barrett JC, Freedman AN, Srivastava S: Revised Bethesda guidelines for hereditary nonpolyposis colorectal cancer (Lynch syndrome) and microsatellite instability. J Natl Cancer Inst 2004, 96:261-8.

12. Kładny J, Lubiński J: Lynch syndrome (HNPCC). Hered Cancer Clin Pract 2008, 6:99-102.

13. Nagasaka T, Rhees J, Kloor M, Gebert J, Naomoto Y, Boland CR, Goel A Somatic hypermethylation of $\mathrm{MSH} 2$ is a frequent event in Lynch syndrome colorectal cancers. Cancer Res 2010, 70:3098-108.

14. Suter CM, Martin DI: Inherited epimutation or a haplotypic basis for propensity to silence? Nat Genet 2007, 39:573.

15. Hitchins MP, Wong JJ, Suthers G, Suter CM, Martin DI, Hawkins NJ, Ward RL: Inheritance of a cancer-associated $M L H 1$ germ-line epimutation. N Eng J Med 2007, 356:697-705.

16. Chan TL, Yuen ST, Kong CK, Chan YW, Chan AS, Ng WF, Tsui WY, Lo MW, Tam WY, Li VS, Leung SY: Heritable germline epimutation of MSH2 in a family with hereditary nonpolyposis colorectal cancer. Nat Genet 2006, 38:1178-83. 
17. Gazzoli I, Loda M, Garber J, Syngal S, Kolodner RD: A hereditary nonpolyposis colorectal carcinoma case associated with hypermethylation of the $\mathrm{MLH1}$ gene in normal tissue and loss of heterozygosity of the unmethylated allele in the resulting microsatellite instability-high tumor. Cancer Res 2002, 62:3925-8.

18. Kovacs ME, Papp J, Szentirmay Z, Otto S, Olah E: Deletions removing the last exon of TACSTD1 constitute a distinct class of mutations predisposing to Lynch syndrome. Hum Mutat 2009, 30:197-203.

19. Ligtenberg MJ, Kuiper RP, Chan TL, Goossens M, Hebeda KM, Voorendt M, Lee TY, Bodmer D, Hoenselaar E, Hendriks-Cornelissen SJ, Tsui WY, Kong CK, Brunner HG, van Kessel AG, Yuen ST, van Krieken JH, Leung SY, Hoogerbrugge N: Heritable somatic methylation and inactivation of MSH2 in families with Lynch syndrome due to deletion of the $3^{\prime}$ exons of TACSTD1. Nat Genet 2009, 41:112-7.

20. Kempers MJ, Kuiper RP, Ockeloen CW, Chappuis PO, Hutter P, Rahner N, Schackert HK, Steinke V, Holinski-Feder E, Morak M, Kloor M, Büttner R, Verwiel ET, van Krieken JH, Nagtegaal ID, Goossens M, van der Post RS, Niessen RC, Sijmons RH, Kluijt I, Hogervorst FB, Leter EM, Gille JJ, Aalfs CM, Redeker EJ, Hes FJ, Tops CM, van Nesselrooij BP, van Gijn ME, Ligtenberg MJ: Risk of colorectal and endometrial cancers in EPCAM deletion-positive Lynch syndrome: a cohort study. Lancet Oncol 2011, 12:49-55.

21. Pérez-Cabornero L, Infante Sanz M, Velasco Sampedro E, Lastra Aras E, Acedo Becares A, Miner Pino C, Durán Domínguez M: Frequency of rearrangements in Lynch syndrome cases associated with $\mathrm{MSH} 2$ : characterization of a new deletion involving both EPCAM and the 5/ part of MSH2. Cancer Prev Res 2011, 4:1556-62.

22. Niessen RC, Hofstra RM, Westers H, Ligtenberg MJ, Kooi K, Jager PO, de Groote ML, Dijkhuizen T, Olderode-Berends MJ, Hollema H, Kleibeuker JH, Sijmons RH: Germline hypermethylation of MLH1 and EPCAM deletions are a frequent cause of Lynch syndrome. Genes Chromosomes cancer 2009, 48:737-744.

23. Munz M, Baeuerle PA, Gires O: The emerging role of EPCAM in cancer and stem cell signaling. Cancer Res 2009, 69:5627-9.

24. Sivagnanam M, Schaible T, Szigeti R, Byrd RH, Finegold MJ, Ranganathan S, Gopalakrishna GS, Tatevian N, Kellermayer R: Further evidence for EPCAM as the gene for congenital tufting enteropathy. Am J Med Genet 2010, 152A:222-4.

25. van der Klift H, Wijnen J, Wagner A, Verkuilen P, Tops C, Otway R, Kohonen-Corish M, Vasen H, Oliani C, Barana D, Moller P, Delozier-Blanchet C, Hutter P, Foulkes W, Lynch H, Burn J, Möslein G, Fodde R: Molecular characterization of the spectrum of genomic deletions in the mismatch repair genes $M S H 2, M L H 1, M S H 6$ and PMS2 responsible for hereditary nonpolyposis colorectal cancer (HNPCC). Genes Chromosomes Cancer 2005, 44:123-138.

26. Jurka J: Evolutionary impact of human Alu repetitive elements. Curr Opin Genet 2004, 14:603-8.

27. Hitchins MP, Burn J: Alu in Lynch syndrome: a danger SINE? Cancer Prev Res 2011, 4:1527-30.

28. Lynch HT, Lynch PM, Lanspa SJ, Snyder CL, Lynch JF, Boland CR: Review of the Lynch syndrome: history, molecular genetics, screening, differential diagnosis and medicolegal ramifications. Clin Genet 2009, 76:1-18.

29. Grandval P, Baert-Desurmont S, Bonnet F, Bronner M, Buisine MP, Colas C, Noguchi T, North MO, Rey JM, Tinat J, Toulas C, Olschwang S: Colon-specific phenotype in Lynch syndrome associated with EPCAM deletion. Clin Genet 2012, 82:97-9.

30. Lynch HT, Riegert-Johnson DL, Snyder C, Lynch JF, Hagenkord J, Boland CR, Rhees J, Thibodeau SN, Boardman LA, Davies J, Kuiper RP, Hoogerbrugge N, Ligtenberg MJ: Lynch syndrome-associated extracolonic tumors are rare in two extended families with the same EPCAM deletion. Am J Gastroenterol 2011, 106:1829-1836.

31. Pineda M, González S, Lázaro C, Blanco I, Capellá G: Detection of genetic alterations in hereditary colorectal cancer screening. Mutat Res 2010, 693:19-31.

32. Caldés T, Blanco I, Soto J, Capellá G, Lázaro C, Cajal T, Mur P, Pineda M, Romero A, Del Valle J, Borràs E, Canal A, Navarro M, Brunet J, Rueda D, Ramón Y: Identyfication of a founder EPCAM deletion in Spanish Lynch syndrome families. Clin Genet 2013, 2013:2013. 10.1111/cge.12152.
33. Kloor M, Voigt AY, Schackert HK, Schirmacher $P$, von Knebel DM, Bläker $H$ : Analysis of EPCAM protein expression in diagnostics of Lynch syndrome. $J$ Clin Oncol 2011, 29:223-7.

34. Pritchard CC, Smith C, Salipante SJ, Lee MK, Thornton AM, Nord AS, Gulden C, Kupfer SS, Swisher EM, Bennett RL, Novetsky AP, Jarvik GP, Olopade OI, Goodfellow PJ, King MC, Tait JF, Walsh T: ColoSeq provides comprehensive Lynch and polyposis syndrome mutational analysis using massively parallel sequencing. J Mol Diagn 2012, 14:357-66.

doi:10.1186/1897-4287-11-9

Cite this article as: Tutlewska et al:: Germline deletions in the EPCAM gene as a cause of Lynch syndrome - literature review. Hereditary Cancer in Clinical Practice 2013 11:9.

\section{Submit your next manuscript to BioMed Central and take full advantage of:}

- Convenient online submission

- Thorough peer review

- No space constraints or color figure charges

- Immediate publication on acceptance

- Inclusion in PubMed, CAS, Scopus and Google Scholar

- Research which is freely available for redistribution

Submit your manuscript at www.biomedcentral.com/submit
( BioMed Central 